\title{
BEHAVIORAL PATTERNS TOWARDS OZONE THERAPY FOR HCV INFECTION
}

\author{
Abd Elaziz, Kh. M. ${ }^{(1)}$; El-Saati, Samya. H. ${ }^{(2)}$ and Habachi, M. H. M. \\ 1) Department of Community, Occupational, and Environmental Medicine, \\ Faculty of Medicine, Ain Shams University. 2) Faculty of Women for Arts, \\ Science and Education, Ain Shams University.
}

\begin{abstract}
During the last decade, Viral Hepatitis C (HCV) has emerged as a new biological threat. Studies were performed in Egypt, between 1999 and 2008 to evaluate the role of ozone therapy for $\mathrm{HCV}$. Whether the disease was in early or late stage, ozone therapy was found to be an effective, safe and, less expensive method in treating hepatitis " $C$ " patients, used alone or in combination with drug therapy. Our study aims to investigate attitudes among physicians and patients towards the disease conditions, predisposing factors and, different therapeutic approaches including ozone therapy for HCV. Using two interview questionnaires, first for physicians $(n=42)$ and the second for patients $(n=50)$, managing $\mathrm{HCV}$ cases, via face to face structured interviews at the site of treatment reception in Cairo and Alexandria. Sites were grouped into three categories: (1) Ministry of Health governmental organizations and university hospitals (2) Army Facilities (3) Private clinics and centers. Snowball sampling method for ozone therapy, and conventional therapists interviewed after obtaining permission from the director of each establishment visited. Negative attitudes towards ozone therapy were observed among our study sample physicians with significant differences when distributed by place of study and physicians specialty. In our study sample $38.1 \%$ of physicians believe that ozone therapy is not scientific evidence based medicine. Moreover, 54.8\% assumed that ozone is an illegal and unapproved therapy for HCV. (93.1\%) of the patients interviewed in governmental organization clinics and university hospitals never received ozone. $62.5 \%$ interviewed in private and army clinics had ozone therapy, and they all had positive attitudes towards ozone therapy for HCV. More research is needed to elucidate the debate concerning ozone therapies.
\end{abstract}


Keywords: oxygen ozone therapy, Hepatitis C, behavioral patterns, physicians, patients, alternative, medicine, (CAM), complementary.

\section{INTRODUCTION}

During the last decade, Hepatitis C Viral (HCV) infection has emerged as a new biological threat (Howard, et al., 2012). Studies were performed in Egypt, between 1999 and 2008 to evaluate the role of ozone therapy for HCV. Ozone therapy was found to be an effective, safe and, less expensive method in Hepatitis "C" patients, used alone or in combination with drug therapy and, weather the condition is early or late ((Mawsouf et al., 2016)). The published Egyptian Demographic Health Survey (EDHS) in 2009, estimated an overall anti-HCV antibody prevalence of $14.7 \%$. (Miller et al. 2010). Egypt Health Issues Survey (EHIS) in 2015, reported that the collected blood samples for testing at the Central Public Health Laboratory of the Ministry of Health and Population (MOHP), individuals age 1-59, for hepatitis testing, the number of individuals with an active hepatitis $\mathrm{C}$ infection was estimated based on the projected population age 1-59 years as of July 1, 2014 (CAPMAS 2015). The quantitative real time Polymerase Chain Reaction (PCR) used at the Central Public Health Laboratory for the detection of HCV RNA, which is indicative of active (current) infection, estimated 3.5 million Egyptians, were found to have an active infection. Six percent had a positive result on the hepatitis $\mathrm{C}$ antibody test, indicating that they had been exposed to the virus. The high level of HCV infection has been attributed in part to the use of inadequately sterilized needles during mass campaigns undertaken to treat schistosomiasis during the 1960s through the early 1980s (Pybus et al., 2000). Hepatitis C 
superseded schistosomiasis as a result of iatrogenic and biological factors, unsafe injection practices (non-sterile needles) (Frank et al., 2000). A large body of literature on the epidemiology of $\mathrm{HCV}$ transmission in Egypt is identifying ongoing iatrogenic exposures as the major driver for $\mathrm{HCV}$ transmission and, short comings in infection control and standard procedures (Miller et al., 2010). The Economic and Social Justice Unit of the Egyptian Initiative for Personal Rights claims that poverty in Egypt with, 26\% of the population live with less than USD 1.6 per day (the national poverty line) and, concludes that hepatitis $\mathrm{C}$ is a socioeconomic condition, hitting the poorest segments of the population. (Gomaa et al. 2017). Hepatitis C virus is known as an RNA virus that replicates in the cytoplasm of liver cells, but is not directly cytopathic << Cytopathic effect or, cytopathogenic effect, CPE) refers to structural changes in host cells that are caused by viral invasion. The infecting virus causes lysis of the host cell or when the cell dies without lysis due to an inability to reproduce $\gg$ (Chen \& Morgan, 2006). The virus has a high ability for replication ranging between 1010 and 1012 virion per day (Neumann et al., 1998). There are six genotypes of HCV (Boyer et al., 2002), HCV genotype 4 (G-4) is the most common in Egypt representing more than $90 \%$ of the cases (Kamal, 2007), The virus also has more than fifty subtypes (Chen \& Morgan, 2006). HCV genome mutate frequently because of the weak error proofreading by the viral RNA polymerase in addition to rapid viral replication (Bukh et al., 1995). Study from Egypt showed late relapse rates of 9\% (El-Raziky et al., 2006). Numerous subtypes and frequent mutations have made difficulties in discovering vaccine for HCV till now. The standard treatment of HCV genotype 4 (HCV- G4) patients was a 
combination of pegylated interferon (PEG-INF) and ribavirin (RBV) for 48 weeks (Abdel-Razek et al., 2015). The efficacy of this combination to treat HCV-G4 patient was small. A worldwide study containing $7163 \mathrm{HCV}$ patient treated by PEG-IFN/RBV showed only 41\% SVR (Pearlman et al., 2011). Also, between 2007 and 2014 the National Program for Control of HCV in Egypt (NCCVH) has treated about 350,000 patients with this combination (Waked et al. 2014) and the result showed SVR between $45 \%$ and $55 \%$ (Esmat, 2013). Then, direct acting antivirals (DAAs), targeting specific sites in $\mathrm{HCV}$ replication complex, a breakthrough in the efficacy of $\mathrm{HCV}$ treatment was introduced. Sustained virologic response (SVR) has been labeled as the evidence supporting, clinically meaningful end point of successful antiviral therapy (Pearlman et al., 2011). The National Committee for Control of Viral Hepatitis (NCCVH) in May 2015 has adopted one IFNbased regimen and two IFN- free regimens for treatment of HCV-G4 patients in Egypt. The IFN- based regimen was composed of SOF+PEG/RBV for 12 wks. The second regimen was for patient ineligible for interferon where the first option was sofosbuvir (SOF) + simeprevir (SIM) for 12 wks., while the second option was SOF+RBV for 24wks (Hézode et al., 2016). The inclusion criteria according to May 2015 guideline include all HCV RNA positive patients between 18 and 70 years, either naive patients or treatment experienced patients without restriction to their fibrosis stage (Abdel-Razek et al,. 2015):. Alternative treatments for $\mathrm{HCV}$ besides instituting lifestyle changes that prolong liver health, approaches for helping the liver damage from Hepatitis $\mathrm{C}$ fall under the domain of Complementary and Alternative 
Medicine (CAM). CAM includes use of natural health products such as vitamins, homeopathic remedies, traditional therapies and herbal medicines (Sinclair, 2001). Complementary Alternative Medicine (CAM) was defined as "those treatments and health care practices that are not an integral part of conventional western medicine, not taught in medical schools, and not generally used in hospitals" (NCCAM, 2012). Ozone therapy purports to increase the amount of oxygen in the body. Ozone introduced to the blood stream directly i.e. intra venous, or indirectly through a procedure called AutoHaemoTherapy (AHT) (Sagai et al. 2011), but also through the ear, rectum and vagina by insufflations, by funneling, bagging and sauna (Altman, 2008) Studies indicate that ozone therapy cures many infections, including hepatitis (McCabe, 2008). For HCV/ozone treatment protocol adopted in Egypt, was blood ozonation, a process whereby: A portion of blood is withdrawn from the patient with $\mathrm{HCV}$; an ozone/oxygen mixture is added to the withdrawn blood; the ozone/oxygen-rich blood is then returned to the patient; Researchers have confirmed that lipid-enveloped viruses are the most sensitive to ozone. As a lipid-enveloped virus, $\mathrm{HCV}$ stands to be one of the pathogens most easily affected by ozone therapy. (Mawsouf et al. 2008) (Zaky et al. 2011). Their studies have shown that ozone therapy can significantly normalize hepatic enzymes and improve measures of general patient health. AutoHemoTherapy (AHT) protocols have showed a viral load reduction on the order of $99.9 \%$, along with a normalization of liver enzyme levels. (Bocci et al. 1994) Results for evaluation of ozone therapy in chronic hepatitis $\mathrm{C}$ showed that it has an effect on improvement of many presenting complaints, and is associated with reduction of liver enzymes levels. (Zaky et 
al. 2011). The World Federation of Ozone Therapy in 2015 Review the Evidence Based Ozone Therapy with over 1300 references. In 2012 the Spanish Association for ozone therapy identified more than 26,000 health professionals practicing ozone in different parts of the world. The information about the properties of ozone, their mechanisms of action, forms and methods of application as well as instructions to correctly apply this valuable therapy following the recommendations of the authors, experts in research and clinical practice of ozone is available (Noci et al., 2015).

\section{AIM OF THE STUDY}

Our study aimed to investigate attitudes among HCV physicians and patients towards different therapeutic approaches including ozone therapy.

\section{SUBJECTS AND METHODS}

A descriptive cross sectional survey study, in which, face to face, structured interviews were conducted between 2012-2014. Using two sets of interviewing questionnaires shaped to include: Physicians and Patients; delivering and receiving $\mathrm{HCV}$ therapy; either conventional and/or, ozone therapy. Each questionnaire had groups of questions to record; 1- Personal Data and social background: Personal and general information about age, gender, education level. 2- Information recorded about their prescriptions and tests done during treatment. HCV history, ways of transmission, predisposing factors and sources of infection, tests, and therapies considered. 3- Attitudes; positive and/or negative regarding the different approaches in disease management, as for considering; Resting in bed, herbal, nutritional, 
natural, spiritual and ozone therapies. 4- Behavioral Patterns and attitudes towards the disease transmission, detection, available therapies: antiviral, surgical, herbal and natural including ozone. 5- Possible explanations for, conventional and alternative therapies, attitudes towards government decision to ban ozone and, possible motives. Questions were formulated as simple (yes) and (no) answers. Unanswered questions, (may be) or, (I don't know) answers were recorded and grouped in items for statistical analysis and comparison. Sites visited were: El Demerdash University Hospital, The Interferon Institute at Heliopolis Hospital, Cleopatra Private Hospital, The Ozone Clinic at Mostafa Kamel Army Hospital, Navy Ras El Tin hospital, Hyperbaric Navy Medical Center, Military Rehabilitation center in Agouza, private clinics and centers. Sites of study were grouped in three categories: (1) Ministry of Health governmental organization and university hospitals (MoH/Gov.Org) (2) Army Facility (3) Private clinics and centers. DATA MANAGEMENT: The developed questionnaires reviewed and the collected data entered onto spread sheets, using the Microsoft Excel® software program, then imported to the Statistic Package for Social Sciences (SPSS). Groups were assessed for differences in variables using the chi-squared test. The conventional 0.05 level of statistical significance was used to determine differences between the groups. INCLUSION CRITERIA FOR PATIENTS: Adult patients (older than 18 years old), with confirmed diagnosis of $\mathrm{HCV}$, at the site of treatment reception and, able to respond to questionnaires. EXCLUSION CRITERIA FOR PATIENTS with late stage liver complications. SAMPLING CONSIDERATION: Snowball sampling method used for ozone therapy, and for conventional therapies, permission 
from the director of each establishment visited was obtained before interviewed subjects on Volunteerism bases after obtaining authorization from the director of each establishment visited. The collected data were entered onto spread sheets, using the Microsoft Excel® software program, then imported to the Statistic Program for Social Science (SPSS), Groups were assessed for differences in variables using the chi-squared test. The conventional 0.05 level of statistical significance was used to determine differences between the groups. LIMITATION OF THE STUDY: Snowball sampling for ozone therapy is not in favour for generalization of the study results.

\section{RESULTS}

FIRST: PHYSICIANS SAMPLE:

Table 1: Demographic distribution of studied physicians:

\begin{tabular}{|l|l|l|}
\hline Demographic characteristics & No (42) & \% \\
\hline Gender: & & \\
Male & 25 & 59.5 \\
Female & 17 & 40.5 \\
\hline Age: & & \\
S50 y o & 27 & 64.3 \\
> 50 y o & 15 & 35.7 \\
\hline
\end{tabular}

Table 2: Comparison between place of study and acceptance of use of ozone among physicians:

\begin{tabular}{|c|c|c|c|c|}
\hline Place of study & Acceptanc & f ozone & & \\
\hline $\begin{array}{l}\text { MoH, Gov.org and, } \\
\text { Uni.Hosp. } \quad \mathrm{N}=22\end{array}$ & $\begin{array}{ll}\text { Yes } & \\
\text { No. } & \% \\
4 & 18.2 \\
\end{array}$ & $\begin{array}{lr}\text { No } & \\
\text { No. } & \% \\
18 & 81.8 \\
\end{array}$ & $\begin{array}{l}X^{2} \\
9.5\end{array}$ & $\begin{array}{l}P \\
0.002\end{array}$ \\
\hline $\begin{array}{lcc}\text { Private } & \text { and } & \text { Army } \\
\text { Facility } & & \mathrm{N}=20\end{array}$ & $13 \quad 65.0$ & 35.0 & & \\
\hline
\end{tabular}


The study sample physicians interviewed in governmental ministry of health organization and university hospitals represented $52.4 \%$ and, the remaining $47.6 \%$ were interviewed in private and Army Facilities (AF). Males were more than females, $59.5 \%$ and, $40.5 \%$ respectively.

Comparison between place of study and acceptance of ozone among physicians showed significant statistical difference $\left(X^{2}=9.5\right)(p<0.05)$.

Table 3: Comparison between physician specialty and acceptance of ozone:

\begin{tabular}{|c|c|c|c|c|c|c|}
\hline \multirow[b]{3}{*}{$\begin{array}{l}\text { Hepatology /liver and } \\
\text { internal diseases specialists } \\
(\mathrm{N}=18)\end{array}$} & \multicolumn{4}{|c|}{ acceptance of ozone } & & \multirow{4}{*}{$\begin{array}{l}\mathrm{P} \\
0.001\end{array}$} \\
\hline & $\begin{array}{l}\mathbf{Y e} \\
\text { No }\end{array}$ & & $\begin{array}{l}\text { No } \\
\text { No. }\end{array}$ & $\%$ & \multirow{3}{*}{$\begin{array}{l}X^{2} \\
11.2\end{array}$} & \\
\hline & 2 & 11.1 & 16 & 88.9 & & \\
\hline$(\mathrm{N}=24)$ & 15 & 62.5 & 9 & 37.5 & & \\
\hline
\end{tabular}

Physician specialty recorded as chosen by participants. Hepatologists and/or liver and internal diseases specialists represented $42.9 \%$ of the sample physicians. Comparing liver doctors and other specialties regarding acceptance of ozone therapy showed highly significant statistical difference $\left(\mathrm{X}^{2}=11.2\right)(\mathrm{p}<0.01)$. 
J. Environ. Sci.

Institute of Environmental Studies and Research - Ain Shams University

Table 4: Distribution of the physician sample according to their attitudes towards recommendations and prescriptions):

\begin{tabular}{|l|ll|lr||}
\hline physician sample & \multicolumn{4}{|l|}{ Prescription patterns } \\
\hline \hline & Yes & & No & \\
& No. & $\%$ & No. & $\%$ \\
PCR for diagnosis & 37 & 88.1 & 5 & 11.9 \\
\hline Surgical Biopsy & 36 & 85.7 & 6 & 14.3 \\
\hline Liver Function Tests & 38 & 90.5 & 4 & 9.5 \\
\hline Antiviral Drugs & 34 & 81.0 & 8 & 19.0 \\
\hline Herbal Supplements & 10 & 23.8 & 32 & 76.2 \\
\hline Bed Resting & 24 & 57.1 & 18 & 42.9 \\
\hline Nutrition support & 30 & 71.4 & 12 & 28.6 \\
\hline Surgical Liver Transplant & 27 & 64.3 & 15 & 35.7 \\
\hline Ozone Therapy & 17 & 40.5 & 25 & 59.5 \\
\hline \hline
\end{tabular}

$88.1 \%(\mathrm{~N}=37)$ of physicians had positive attitudes towards using and recommending PCR for diagnosis, 85.7\% ( $\mathrm{N}=38)$ surgical biopsies and, 90.5\% ( $\mathrm{N}=38)$ responded having positive attitudes towards liver function tests. $81.0 \%(\mathrm{~N}=34)$ of physicians recommended for the use of antiviral drugs. Positive attitudes towards herbal supplements were present in $23.8 \%$ $(\mathrm{N}=10)$ of physicians. $57.1 \%$ consider bed- resting their patients and , 71.4\% ( $\mathrm{N}=30)$ favor special diet and nutrition support. $64.3 \%(\mathrm{~N}=27)$ had positive attitudes towards surgical liver transplants and $40.5 \%(\mathrm{~N}=17)$ had positive attitudes towards ozone therapy for $\mathrm{HCV}$. 
Table 5: Distribution of the physician sample according to their attitudes towards ways of contamination, and HCV predisposing factors:

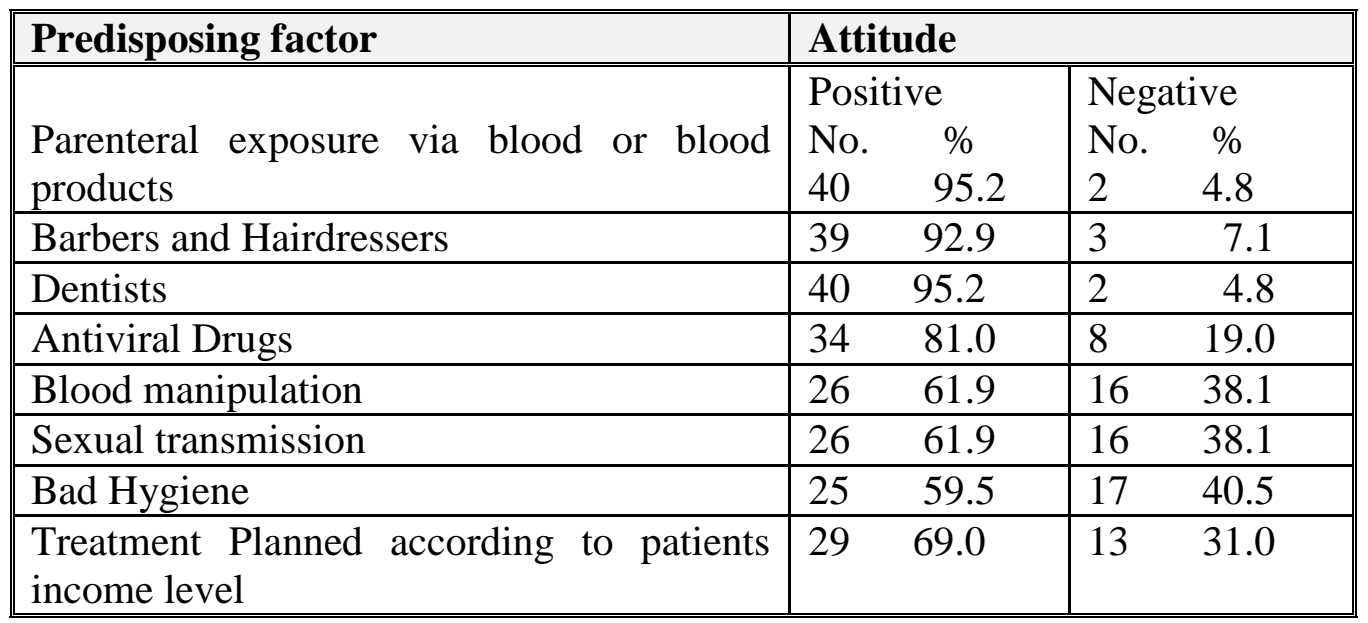

Regarding the patients personal hygiene as a background for infection with $\mathrm{HCV}, 40.5 \%$ of physicians excluded the possibility that poor hygiene may be a predisposing factor for infection. 66.7\% $(n=28)$ of physicians responded that $\mathrm{HCV}$ is a disease affecting both equally rich and poor, $11.9 \%$ described HCV as a disease of rich people and $19.0 \%$ as poor men disease.

Table 6- Distribution of the physician sample according to their attitudes towards different therapies:

\begin{tabular}{|l|ll|lc|}
\hline Different Therapies & \multicolumn{3}{l|}{ Attitudes } & \\
\hline \hline & \multicolumn{2}{|l|}{ Positive } & \multicolumn{2}{l|}{ Negative } \\
& No. $\%$ & No. & $\%$ \\
\hline herbal supplements & 12 & 28.6 & 30 & 71.4 \\
\hline ozone therapy & 19 & 45.2 & 23 & 54.8 \\
\hline
\end{tabular}


Table 7- Distribution of the physician sample according to their interpretations for the reasons behind banning the ozone prescriptions for $\mathrm{HCV}$ :

\begin{tabular}{|c|c|c|c|}
\hline Possible reasons for banning ozone & $\begin{array}{l}\text { Yes } \\
\text { No. }\end{array}$ & $\begin{array}{l}\text { No } \\
\text { No. }\end{array}$ & $\%$ \\
\hline Ozone is not effective therapy & 2866.7 & 14 & 33.3 \\
\hline Ozone is not scientific evidence medicine & $\begin{array}{ll}16 & 38.1 \\
\end{array}$ & 26 & 61.9 \\
\hline $\begin{array}{l}\text { Ozone Conflicts Pharmacological Industry } \\
\text { interests }\end{array}$ & $29 \quad 69.0$ & 13 & 31.0 \\
\hline
\end{tabular}

SECOND: PATIENTS SAMPLE:

Table 8: Demographic distribution of studied group's patients:

\begin{tabular}{|c|c|c|c|}
\hline \multicolumn{2}{|c|}{ Demographic distribution } & $\begin{array}{l}\text { No } \\
(n=50)\end{array}$ & $\%$ \\
\hline Gender: & $\begin{array}{c}\text { Male } \\
\text { Female }\end{array}$ & $\begin{array}{l}34 \\
16\end{array}$ & $\begin{array}{l}68.0 \\
32.0\end{array}$ \\
\hline Age: & $\begin{array}{l}\leq 50 \mathrm{y} \mathrm{o} \\
>50 \text { y o }\end{array}$ & $\begin{array}{l}18 \\
32\end{array}$ & $\begin{array}{l}36.0 \\
64.0\end{array}$ \\
\hline
\end{tabular}

Patients interviewed in governmental organization represented $58.0 \%$ and, the remaining $42.0 \%$ were interviewed in private and army clinics. $74 \%$ of the patients study sample received treatment in governmental organization/ministry of health hospitals and university hospitals, $48 \%$ in private clinics, and $16 \%$ in army hospitals.

Table 9: Comparison between place of study and acceptance of ozone among patients:

\begin{tabular}{|c|c|c|c|c|c|}
\hline place of study & Ozone ac & ptance & \multirow[b]{2}{*}{$\begin{array}{l}\text { Total } \\
\text { No. } \% \\
23 \quad 100\end{array}$} & \multirow{3}{*}{$\begin{array}{l}X^{2} \\
22.6\end{array}$} & \multirow{3}{*}{$\begin{array}{l}P \\
0.00\end{array}$} \\
\hline $\begin{array}{l}\text { MoH, Gov.Org } \\
\mathrm{N}=29\end{array}$ & $\begin{array}{lr}\text { Yes } & \\
\text { No. } & \% \\
2 & 6.9\end{array}$ & $\begin{array}{lc}\text { No } & \\
\text { No. } & \% \\
27 & 93.1\end{array}$ & & & \\
\hline $\begin{array}{l}\text { Private } \text { and } \\
\text { Army } \mathrm{N}=21\end{array}$ & $\begin{array}{ll}15 & \mathbf{7 1 . 4}\end{array}$ & $\begin{array}{ll}6 & 28.6\end{array}$ & $21 \quad 100$ & & \\
\hline
\end{tabular}


$93.1 \%$ of the patients interviewed in governmental organization clinics and university hospitals never received ozone. While, $62.5 \%$ interviewed in private and army clinics had ozone therapy. Comparison between place of study and acceptance of ozone among patients showed highly significant statistical difference. $X^{2}=22.6, \quad p<0.001$.

Table 10: Comparison between patient's level of education and acceptance of ozone among patients:

\begin{tabular}{|c|c|c|c|c|c|}
\hline level of education & \multirow[b]{2}{*}{$\begin{array}{l}\text { Yes } \\
\text { No. } \% \\
12 \quad 52.2\end{array}$} & \multirow[b]{2}{*}{$\begin{array}{l}\text { No } \\
\text { No. \% } 11 \\
47.8\end{array}$} & $\begin{array}{l}\text { Total } \\
(\mathrm{N}=50)\end{array}$ & \multirow{3}{*}{$\begin{array}{l}X^{2} \\
6.2\end{array}$} & \multirow{3}{*}{$\begin{array}{l}\mathrm{P} \\
0.17\end{array}$} \\
\hline Highly educated & & & $\begin{array}{lc}\text { No. } & \% \\
23 & 100\end{array}$ & & \\
\hline Others & $\begin{array}{ll}5 & 18.5\end{array}$ & 2281.5 & 100 & & \\
\hline
\end{tabular}

Acceptance of ozone therapy showed no significant difference among highly educated patients compared to others. $\quad\left(X^{2}=6.2\right)(p>0.05)$.

Table 11: Distribution of the study sample patients according to the ozone therapy modalities received and their attitudes towards cost of treatment and perceived effectiveness :

\begin{tabular}{|c|c|c|c|}
\hline Ozone Therapy Received & $\begin{array}{l}\mathrm{Ye} \\
\mathrm{No} \\
20\end{array}$ & $\begin{array}{c}\% \\
40.0\end{array}$ & \multirow[t]{7}{*}{$\begin{array}{lc}\text { NO } & \text { OZONE } \\
\text { No. } & \% \\
30 & 60.0\end{array}$} \\
\hline Intra Venous/Auto-haemotherapy & 17 & 34.0 & \\
\hline Ozone Insufflations & 17 & 34.0 & \\
\hline Ozone after/with Antiviral drugs & 12 & 24.0 & \\
\hline Only treated with ozone & 9 & 18.0 & \\
\hline Is Ozone treatment expensive? & 10 & 20.0 & \\
\hline Positive attitude towards ozone & 20 & 40.0 & \\
\hline
\end{tabular}


Forty percent $(\mathrm{N}=20)$ of the patients sample received ozone therapy. $34 \%$ had ozone intravenous / AHT, and equally, 34\% had insufflations. Twelve patients received ozone after/with antiviral drugs. Nine patients received ozone exclusively. Half of them expressed that ozone was expensive and represented a budget burden and all of them had positive attitudes towards the therapy.

Distribution of the study sample patients according to ozone therapy reception showed no significant difference between mean age groups, genders, age of infection, and level of education.

OTHER FINDINGS: Presence of records: 14 out of 42 interviewed sample physicians had a negative response to record keeping. While half of the interviewed patients had HCV history of more than 3 years, $34 \%$ discovered the infection by routine examination and, $64 \%$ had symptoms of disease. $60 \%$ of the patients study sample did not receive antiviral therapies. $25 \%$ of patients who had ozone therapy also had antiviral therapies. Half of the patients treated with ozone had it intravenously, and another half had rectal insufflations. Half of the total sample patients considered ozone therapy as expensive and represented a burden on their budget. Regardless the therapies they follow almost half of the patients sample believed that drug industry had interests in banning ozone, $2 \%$ think that money interests are not involved in medical and health care administration and research. The majority of patients (96\%) consider PCR a diagnostic tool, 32\% accepts surgical biopsy for diagnosis, $70 \%$ consider antiviral therapy and, 12\% considered liver 
transplant if possible. Regarding acceptance of herbal and natural therapies, $64 \%$ of the sample patients showed positive attitudes.

\section{DISCUSSION \& CONCLUSION}

Attitudes toward therapeutic measures: Negative attitudes towards Alternative and Complementary Medicine (CAM) were observed among our study sample physicians. $71.4 \%$ of our study sample physicians refuse herbal, ozone and diet therapies for $\mathrm{HCV}$, controversially, $64.0 \%$ of patients had positive attitudes. In our study sample physicians $38.1 \%$ believe that ozone is not scientific evidence based medicine and controversially $35.1 \%$ believe that it was banned because it conflicts drug industry and corporations interests. Moreover, $54.8 \%$ assumed that ozone is illegal and unapproved therapy for HCV. Studies exploring the prevalence and patterns of knowledge about, referrals to, training in, and practice of complementary and alternative medical therapies and their perceived effectiveness are undertaken. Physicians in the province of Ontario, Canada, as an example for comparison revealed that $72 \%$ reported referring patients for alternative medicine therapies, and $20 \%$ had training in and $20 \%$ practiced some form of alternative medicine. (Ko and Berbrayer, 2000). Sixty-four percent of our study sample patients showed positive attitudes towards herbal and alternative therapies, while only $23 \%$ of our study sample physicians did. In a study to evaluate the attitudes of physicians at an academic medical center toward complementary and alternative medicine (CAM) therapies and the physicians' knowledge base regarding common CAM therapies, in Rochester, MN, USA. Most physicians agreed that they should have knowledge about the most 
prominent CAM treatments and that the spiritual beliefs and practices of patients are important for their healing. Although 67\% agreed that some CAM therapies hold promise for the treatment of symptoms, conditions and diseases, $70 \%$ of the physicians stated that the current practice of CAM therapies in the United States represents a threat to the health of the public. (Dietlind et al., 2006). In a study involving liver disease and CAM, up to $39 \%$ of patients attending liver disease clinics admitted to using some form of $\mathrm{CAM}$ at least once during the preceding month. The average use of CAM in liver disease patients was reported to be $41 \%$ (range $33 \%$ to $75 \%$ ) in a study involving six different institutions (Seeff et al. 2001). A study in Florida (Giese, 2000) showed $43 \%$ of patients who used CAM used it for liver disease. One study that specifically surveyed clinic patients (Bruguera et al., 2004) found that of $37 \%$ of patients that had used or were using CAM, 20\% were using the CAM therapy because of chronic hepatitis and $17 \%$ were using it for other reasons. The use of CAM for liver disease may actually be higher outside western populations; a study looking at CAM use in Taiwanese patients found as many as $66 \%$ of patients used CAM (Yang et al., 2002).

The liver depends for $80 \%$ of its blood supply on other organ systems (Charbon et al., 1989). So, bed rest is favorable for the nutrition and function of the liver by modifying its blood supply (Yong-Song et al., 2013). In our present study $57.1 \%$ of physicians recommended bed rest and, $71.4 \%$ considered proper nutrition while managing HCV. Sixty four percent $(n=32)$ of our study patients considered bed rest and good nutrition as positive factors for a cure. $21.4 \%(\mathrm{~N}=9)$ of our study physicians had negative attitudes 
towards bed rest. And five (11.9\%) physicians claimed negative attitudes towards nutritional support. $H C V$ being a viral infection, only antiviral drugs will control it they claimed. So explained by the $78.6 \%(\mathrm{~N}=7)$ of the sample physicians had positive attitudes toward; antiviral drugs and the 64\% ( $\mathrm{N}=27)$ in favor of surgical liver transplants. Liver transplant activity in the Arab world until 2013 was evaluated and arranged according to date of the first transplant revealed that Egypt since 1991, had 56\% (2,140 living donor and deceased donor liver transplantation) of the total of 3,804, in 11 countries members of the Arab League States (Khalaf et al., 2014). Saudi ranked second with 1,338 (35\%) liver transplant operations. Compared to physicians, patients showed less acceptance towards surgical interventions; 68\% ( $\mathrm{N}=34)$, and towards antiviral drugs $34 \%(\mathrm{~N}=17)$. The relevance of these findings reveal that the increasing demand and scarce supply of organs in the Arab World, is more a physician concern than a patient concern. These facts generate concern related to organ trafficking and transplant tourism (Khalaf et al., 2014). Attitudes toward Disease transmission: The risks of transmission of hepatitis $\mathrm{C}$ during sexual relations or from a mother to her child at birth or when breastfeeding are low, and few Egyptian Health Issues Survey (EHIS) responded mentioning those as possible ways to contract hepatitis C. Around 1 in 5 women and 1 in 7 men thought incorrectly that casual physical contact with an infected person was a way in which hepatitis $\mathrm{C}$ is transmitted (ElZanati et al., 2015). In our study physicians $38.1 \%(\mathrm{n}=16)$ affirmed the possibility of sexual transmission and, $38.1 \%(n=16)$ denied. From the total physicians sample $(n=42)$, regarding behavioral related risk factors for HCV transmission and possible ways of infection; the majority of interviewed 
physicians reported positive answers regarding the parentral nature of the infection, via contaminated blood or, blood products $(n=40)(95.2 \%)$, at the barbers and hairdressers $(92.9 \%)$ and/or at dentists (95.2\%). Drugs (81.0\%), blood manipulation (61.9\%), and sexual transmission, (61.9\%). These attitudes are in accordance with studies of risk factors of $\mathrm{HCV}$ infection showing that more than one third of subjects $(39.6 \%)$ who had jobs related to blood exposure, $47.5 \%$ of drug abusers, were positive (Awadalla, 2011). Ozone Therapy Patients: Forty percent $(n=20)$ of our study patients received ozone therapy, thirty four percent $(n=17)$ had Intravenous ozone (AHT) and, $(n=17)$ thirty four percent had ozone insufflations. Twelve patients from our study sample (24\%) had ozone after having received conventional drug therapies and eighteen percent only had ozone as treatment. All the interviewed patients had positive attitudes towards ozone for HCV. Half of them claimed ozone therapy was burden on their budget. Physicians attitudes towards ozone and the limitation of its use in governmental organization, ministry of health and, university hospitals for the treatment of $\mathrm{HCV}, 35.7 \%(\mathrm{~N}=15)$ assumed that ozone therapy conflicts pharmaceutical industry and corporate interests, while $33.3 \% \quad(\mathrm{~N}=14)$ disapproved this argument. The remaining $31 \%(\mathrm{~N}=13)$ failed to respond. Sixteen physicians $(38.1 \%)$ claimed ozone is not scientific evidence medicine and seventeen $(40.5 \%)$ failed to respond. Nine $(21.4 \%)$ claimed scientific evidence is not the true cause of limitation of ozone use.

Investigating the actual research, internet information, and verbal inquiries about ozone clinics and organizations showed that ozone therapy is 
only provided in private and army clinics. The cold plasma ozone generation method (or dielectric barrier discharge method) is to produce ozone (Čech et $a l ., 2017)$. In Russia, Ukraine and China and Ozone therapy is commonly used and most of the patients are treated with ozone therapy (Sagai et al., 2011): The American National Institute of Health's Office of Alternative Medicine developed a classification of Complementary and Alternative Medicine (CAM) that differentiates seven categories and, includes intravenous ozone as one of the pharmacological and biologic treatments (Gordon, 1996). Others advocate ozone as a medical act and, the World Federation of Ozone Therapy in 2015 Reviewed the Evidence Based Ozone Therapy with over 1300 references (Noci et al. 2015). Relevance of the Study: Our study was carried on patients receiving and delivering treatments for $\mathrm{HCV}$. Thus the real figures of the population behavior towards CAM therapies may be exceed the current figures of data, since self medicated patients will generally not be met at treatment sites. A study in Alexandria, Egypt, aimed to describe the prevalence, pattern and reasons for selfmedication among adults, found the majority practiced self-medication (86.4\%), mostly using both drugs and CAM (77.5\%). The most frequently used CAM, were herbs (91.6\%), spiritual healing (9.4\%) and, cupping and acupuncture (6.4\%). CAM improved the condition according to $95.2 \%$ of users (El-Nimr et al., 2015). These findings is in accordance with alternative and complementary medicine for liver diseases provides benefits by regulating immunity, controlling disease progression, improving quality of life, and prolonging survival (Guan et al., 2013). Ozone is not expensive and not patentable. It is regretful that local health authorities, concerned by the 
increased medical costs, do not take advantage of this inexpensive act. Unlike all other complementary approaches, the biochemical, physiological and pharmacological actions drawn out by ozone are in the realm of orthodox medicine (Bocci, 2011). This study highlights the need for educational interventions and the importance of providing physicians ready access to evidence-based information regarding ozone therapies as well as complementary and alternative medical acts.

\section{RECOMMENDATIONS}

More research is needed to elucidate the debate concerning ozone therapy.

\section{REFERENCES}

Abdel-Razek, W. and, Waked I. (2015): Optimal therapy in genotype 4 chronic hepatitis C: finally cured? Liver International: $35: 27-34$.

Altman,N. (2007). How is Ozone Therapy Applied? From: The Oxygen Prescription.by Nathaniel Altman. 3rd Revised and Expanded edition of Oxygen Healing Therapies. Inner Traditions Bear and Company publication. Chapter 5. pp 68 -80.

Awadalla, H., Ragab, M., Nassar, N., Osman, M. (2011) : Risk factors of hepatitis $\mathrm{C}$ infection among Egyptian blood donors. Central European Journal of Public Health; 19 (4): 217-221.

Bocci, V., Luzzi, E. and, Corradeschi, F.(1994) Studies on the biological effect of ozone: Evaluation of immunological parameters and tolerability in normal volunteers receiving ambulatory autohaemotherapy, Biotherapy;7:83-90.

Boyer, J. L., Muggia, F. M., Chang, E. B., Shapiro, C. L., Spector, S. A., Collyar, D. E., DeLeve, L. D. (2002) National Institutes of Health Consensus Development Conference Statement: Management of hepatitis C: Hepatology. 36 (5 Suppl 1) :S3-20. 
Bruguera M, Barrera JM, Ampurdanes S, Forns X, Sánchez Tapias JM. (2004): Use of complementary and alternative medicine in patients with chronic hepatitis C. Medicina clínica Facultad de Medicina de Barcelona.:Med Clin (Barc);122(9):334-5.

Bukh, J., Miller, R. H., \& Purcell, R. H. (2015). Genetic heterogeneity of hepatitis $\mathrm{C}$ virus: quasispecies and genotypes. In Seminars in liver disease 15: 41-63.

Central Agency for Public Mobilisation and Statistics. Report issued by: Economic and Social Justice Unit. Knowledge and Prevalence of Hepatitis B and C. CAPMASTAT data 2012-2013. Ministry of Health and Population, El-Zanaty and Associates and, ICF International. 2015. Egypt Health Issues Survey 2015. Cairo, Egypt and Rockville, Maryland, USA: Ministry of Health and Population and ICF International. chapter 3: pp. 25-50.

Čech, J., Brablec, A., Černák, M, Puač, N., Selaković, N. and, Petrović, Z. (2017) Mass spectrometry of diffuse coplanar surface barrier discharge: influence of discharge frequency and oxygen content in N2/O2 mixture. The European Physical Journal ; 71: 27.

Charbon, G.A. and, Anderson, M.F. (1989) Progress report: Hepatic haemodynamics as related to blood flow through gut, spleen, and pancreas. journal of the British Society of Gastroenterology. Gut: $30: 265-278$

Chen, S.L., \& Morgan,T.R. (2006): The Natural History of Hepatitis C Virus (HCV) Infection. International Journal of Medical Sciences, 3(2), 47-52.

Darwish NM , Abbas MO and, Abdelfattah FM, (1992): Hepatitis C virus infection in blood donors in Egypt. The Journal of the Egyptian Public Health Association.67(3-4):223-36.

Dietlind L., Wahner-Roedler 1., Ann Vincent 1., Peter L., Elkin 1., Laura L., Loehrer 1., Stephen S., Cha and Brent A. Bauer (2006): Physicians' Attitudes Toward Complementary and Alternative Medicine and Their Knowledge of Specific Therapies: A Survey at an Academic Medical Center. Evidence Based Complementary and Alternative Medicine; 3(4): 495-501. 
El-Nimr, N.A. , Wahdan, I.M.H., Wahdan A.M.H. and, Kotb, R.E. (2015): Self-medication with drugs and complementary and alternative medicines in Alexandria, Egypt: prevalence, patterns and determinants. Eastern Mediterranean Health Journal. ;21(4):256-65.

El-Raziky M, El-Akel W, Soliman M, Kafrawy El, Abdel-Hamid M, Esmat G. HCV relapse in sustained responders to interferon therapy for chronic hepatitis $\mathrm{C}$ genotype 4. Proceedings of the European Society for Clinical Virology 2006; Birmingham, England, J Clin Virol , 36 (2)S141

El-Zanati, F. et al. (2015): Egypt Health Issues Survey, Ministry of Health and Population, El-Zanaty and Associates and, ICF International. International. Central Agency for Public Mobilisation and Statistics. Report issued by: Economic and Social Justice Unit: Knowledge and Prevalence of Hepatitis B and C. chapter 3: pp. 25-50.

Esmat, G. (2013): Hepatitis C in the Eastern Mediterranean Region Eastern Mediterranean Health Journal | WHO Editorial 19 (7): 587- 588

Frank, C., Mohamed, M.K., Strickland, G.T., Lavanchy, D., Arthur, R.R., Magder, L.S., El Khoby, T., Abdel-Wahab, Y., Aly Ohn, E.S., Anwar, W. and, Sallam, I. (2000). The role of parenteral antischistosomal therapy in the spread of hepatitis $\mathrm{C}$ virus in Egypt. Lancet. 355 (9207) 887-891

Giese, LA. (2000): A study of alternative health care use for gastrointestinal disorders. Gastroenterology Nursing 23:19-27.

Gomaa, A., Allam, N., Elsharkaway, El Kassas, M. and, Waked, I. (2017): Hepatitis $\mathrm{C}$ infection in Egypt: prevalence, impact and management strategies. Dove Press Hepatic Medicine : Evidence and Research; 9: 17-25.

Gordon, J.S. (1996): Alternative medicine and the family physician. American Family Physician., 15: 2218-2220. 
Guan, N., Deng, J., Li, T., Xu, X., Irelan, J.T. and, Wang M.W. (2013): Label-free monitoring of $\mathrm{T}$ cell activation by the impedancebased xCELLigence system. Molecular BioSystems, Royal Society of Chemistry:9(5):1035-43.

Hézode, C., Chevaliez, S., Scoazec, G., Soulier, A., Varaut, A., BouvierAlias, M., Ruiz, I., Roudot-Thoraval, F., Mallat, A., Féray, C. and, Pawlotsky, J. (2016) Retreatment with sofosbuvir and simeprevir of patients with hepatitis $C$ virus genotype 1 or 4 who previously failed a daclatasvir-containing regimen. Hepatology. 63(6):1809-16

Howard, C.R. and, Fletcher N.F., (2012): Emerging virus diseases: can we ever expect the unexpected? Emerging Microbes \& Infections, 1(12): e46.

Kamal, S.M. (2007): Acute hepatitis C: a systematic review.The American Journal of Gastroenterology, 103(5):1283-97.

Khalaf,H., Marwan,I., Al-Sebayel,M., (2014): Status of Liver Transplantation in the Arab World. Transplantation Society Regional Perspectives. 15;97(7):722-4.

Ko, G.D. and, Berbrayer D. (2000): Complementary and alternative medicine: Canadian physiatrists' attitudes and behavior. Archieves of Physical Medicine and Rehabilitation;81(5):662-7.

Mawsouf, M.N. and, Tanbouli,T.T. (2016): Ozone Therapy in patients with viral Hepatitis C Ten Years Experience Publication: Cancer Institute, Cairo University, Cairo Medical Clinics, retrieved from: Library of Medical Research, Ozone Research Repository, Ozone and Oxygen Research Database.

Mawsouf,M.N., Re,L., Menéndez-Cepero,S. and, Rosales,F. (2008) Ozone Therapy: Clinical and Basic Evidence of Its Archives of Medical Research in Therapeutic Potential. 39(1):17-26

McCabe, E. (2008): Medical Ozone Therapies: Fifty years of overlooking a proven answer for diseases like cancer and now AIDS. Ed McCabe, Research Journalist. Energy Publications. (315) 6849284. 
Miller D.W. and, Abu-Raddad L.: Evidence of intense ongoing endemic transmission of hepatitis $\mathrm{C}$ virus in Egypt. Proceedings of the National Academy of Sciences of the United States of America (PNAS), Journal of the National Academy of Sciences, U S A. 17;107(33):14757-62

National Center for Complementary and Integrative Health NCCIH Pub No.: D347 U.S. https://nccih.nih.gov/ Department of Health \& Human Services, National Institutes of Health, USA.gov.

Neumann, A.U., Lam, N.P., Dahari, H., Gretch, D.R., Wiley, T.E., Layden, T.J. and, Perelson, A.S.: Hepatitis C viral dynamics in vivo and the antiviral efficacy of interferon-alpha therapy. Science. 282(5386):103-7.

Noci,J.B., Soler,J.R., Moraleda, M.G., Cepero, S.M. and, Re,L., (2015) World Federation of Ozone Therapy WFOT's. Review on Evidence Based Ozone Therapy - First edition . retrieved online from: www.wfoot.org/ scientific library (2017).

Pearlman,B.L. and, Traub,N. (2011) Sustained Virologic Response to Antiviral Therapy for Chronic Hepatitis C Virus Infection: A Cure and So Much More. Clinical Infectious Diseases 52 (7): 889-900.

Pybus,O.G., Drummond, A.J., Nakano, T., Robertson, B.H. and, Rambaut, A.( 2010): The Epidemiology and Iatrogenic Transmission of Hepatitis C Virus in Egypt: A Bayesian Coalescent Approach. by the Society for Molecular Biology and Evolution. Mol. Biol. Evol. 20(3):381-387.

Sagai, M. amd, Bocci V. (2011): Mechanisms of Action Involved in Ozone Therapy: Is healing induced via a mild oxidative stress? Medical Gas Research. National Center for Biotechnology Information, U.S. National Library of Medicine. Published by BioMed Central; 1: 29.

Seeff, L.B., Lindsay, K.L., Bacon, B.R., Kresina, T.F. and, Hoofnagle, J.H. (2001): Complementary and alternative medicine in chronic liver disease. Journal of Hepatology;34:595-603. 
Sinclair A. (2001): Herbal medicine's on-the-net garden grows. Canadian Medical Association Journal CMAJ;165:1378.

Waked, I., Doss, W., El-Sayed, M.H., Estes, C., Razavi, H., Shiha, G., Yosry, A. and, Esmat.G. (2014), The current and future disease burden of chronic hepatitis $\mathrm{C}$ virus infection in Egypt. Arab Journal of Gastroenterology. 15(2):45-52.

Yang ZC, Yang SH, Yang SS, Chen DS. (2002): A hospital-based study on the use of alternative medicine in patients with chronic liver and gastrointestinal diseases. Am J Chin Med.;30:637-43.

Yong-Song, G. and, Quing, H. (2013): A Current Update on the Rule of Alternative and Complementary Medicine in the Treatment of Liver Diseases. Evidence-Based Complementary and Alternative Medicine Article ID 321234, 10 pages

Zaky S, Kamel SE, Hassan MS, Sallam NA, Shahata MA, Helal SR, Mahmoud H. (2011) Preliminary results of ozone therapy as a possible treatment for patients with chronic hepatitis C. J Altern Complement Med. 17(3):259-63.

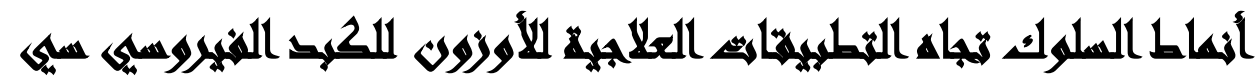

[r]

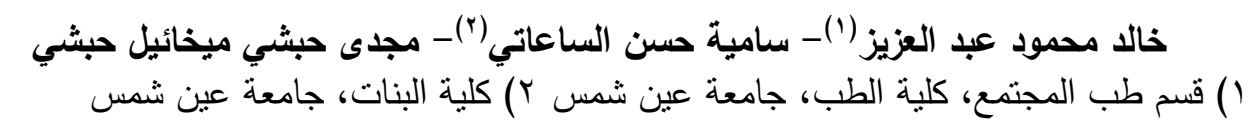

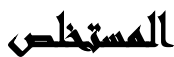

ظهر مرض الكبد الفيروسي سي كتهديد بيولوجى خلال العقدين الماضيين. فأجريت العديد من

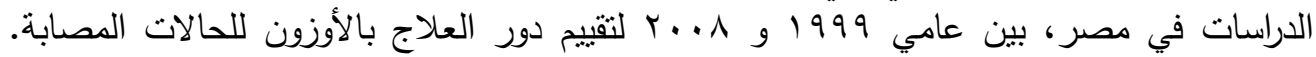

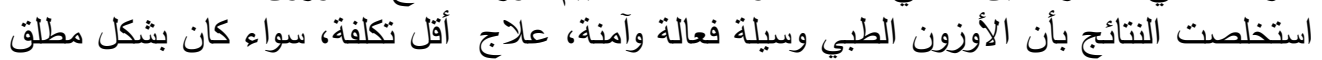

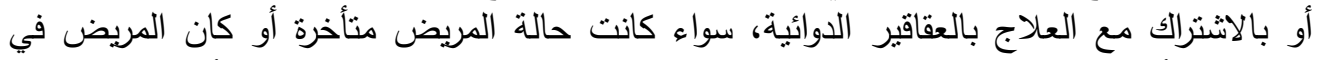

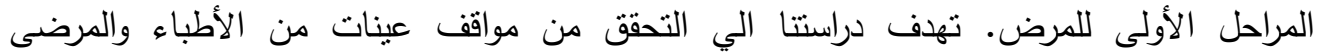

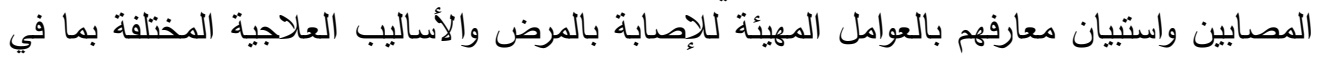

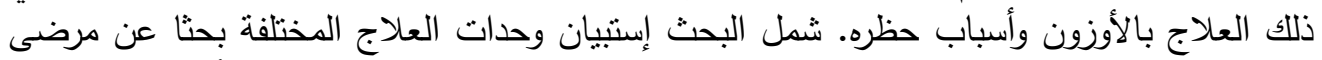

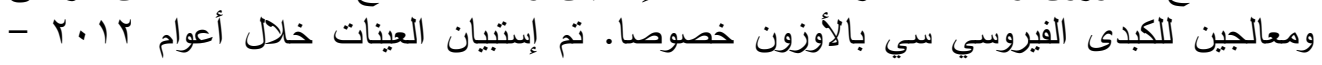




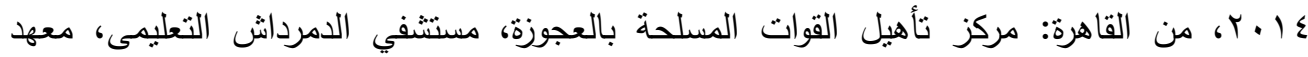

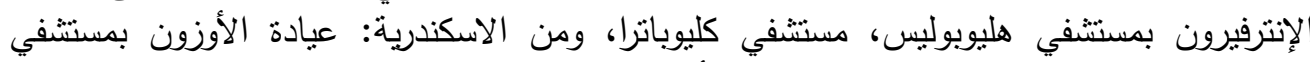

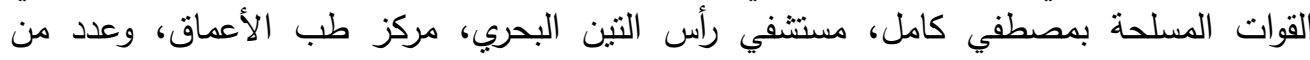

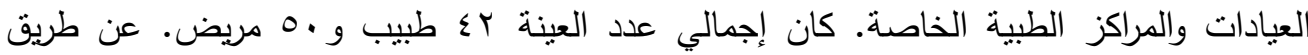

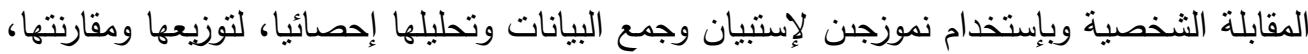

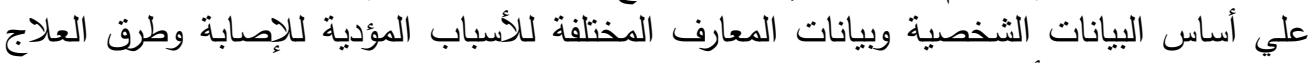

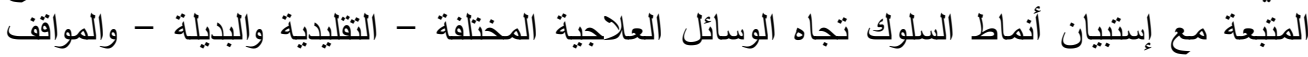

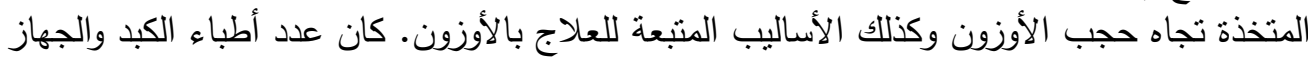

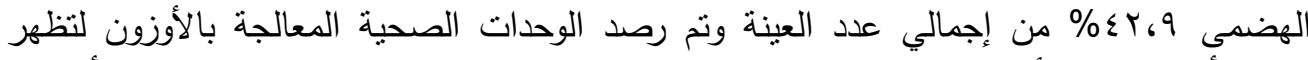

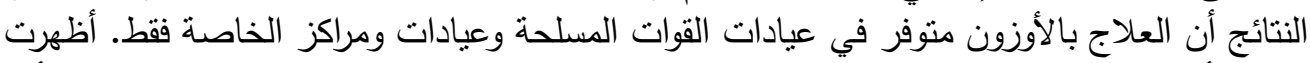

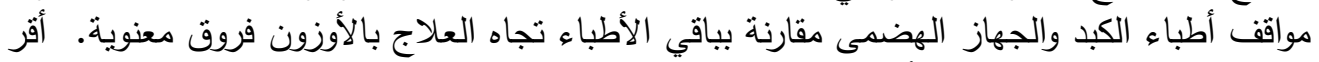

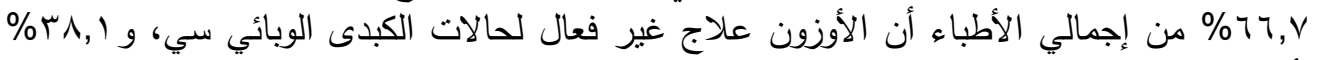

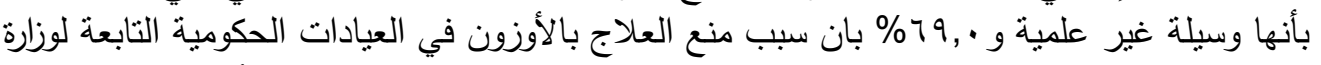

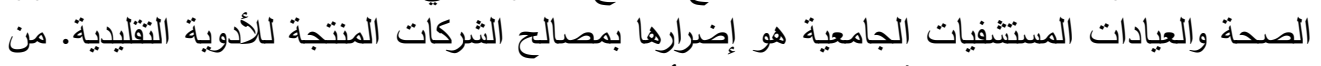

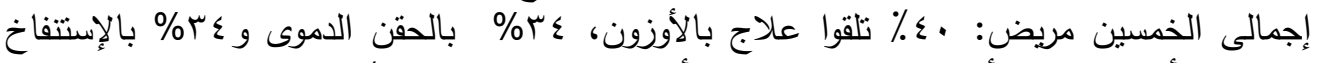

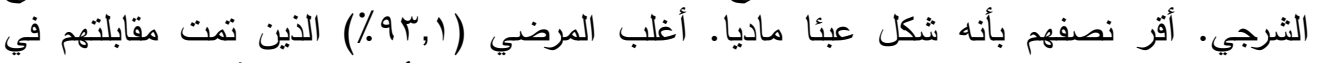

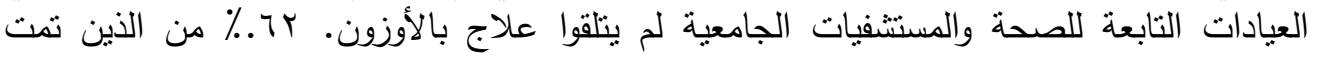

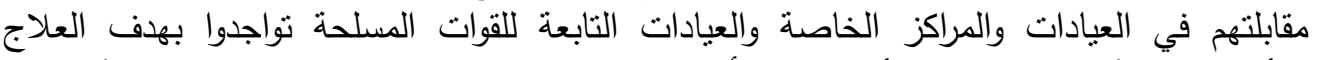

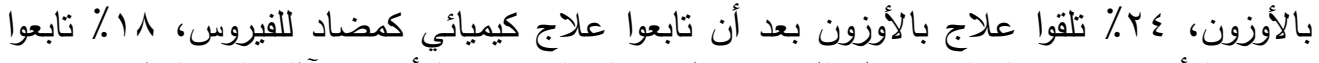

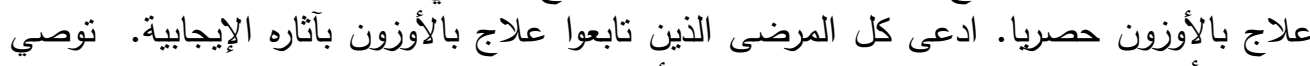

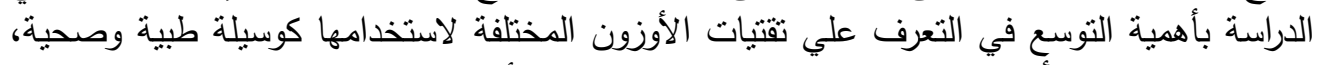

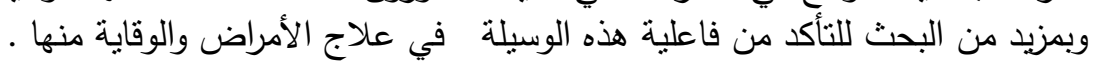

